\title{
Neutron Flux Parameter for In-Vivo testing Boron Neutron Capture Therapy (BNCT) on Radial Piercing Beam Port Kartini Nuclear Reactor by Monte Carlo N- Particle Extended (MCNPX) Simulation Method
}

\author{
Ikna Urwatul Wusko ${ }^{1}$, Nur Hidayah ${ }^{2}$ \\ \{iknaurwatul@gmail.com ${ }^{1}$, nur.hidayah1802@gmail.com $\left.{ }^{2}\right\}$ \\ Industrial Engineering Study Program of Science and Technology Faculty Sari Mulia \\ University, Indonesia ${ }^{1}$ \\ Information System Study Program of Science and Technology Sari Mulia University, \\ Indonesia ${ }^{2}$
}

\begin{abstract}
The research of neutron flux parameters for in vivo testing BNCT on radial piercing beamport Kartini Nuclear Reactor was carried out using the MCNPX simulation method. BNCT is an alternative type of nuclear therapy that utilizes a ${ }^{10} \mathrm{~B}(\mathrm{n}$, $\alpha{ }^{7} \mathrm{Li}$ reaction that produces a total kinetic energy of $2.79 \mathrm{MeV}$. Linear Energy Transfer (LET) of $\alpha$ particles and ${ }^{7} \mathrm{Li}$ recoil will be deposited locally in the range of 5-9 $\mu \mathrm{m}$. The determination of neutron flux was carried out after optimizing the collimator through the translucent port of the Kartini Reactor with a neutron source according to the output of the collimator. Neutron flux obtained after irradiation with an optimum concentration of boron 10 was $47 \mathrm{~g}$ of output data tumors for skin tissue.
\end{abstract}

Keywords: Neutron Flux, BNCT, Kartini Nuclear Reactor, In vivo testing

\section{Introduction}

Boron Neutron Capture Therapy (BNCT) is a radiation therapy using non-radioactive nuclides $10 \mathrm{~B}$ to capture thermal neutrons with a very high probability. This nuclear reaction results in two $\alpha$ and 7Li particles with a range on the tissues confined to a single cell diameter. The result of this reaction has a high Linear Energy Transfer (LET) character of approximately $150 \mathrm{keV} \mu \mathrm{m}-1$ with a range of up to $7.1 \mu \mathrm{m}$ for $\alpha$ particles and $175 \mathrm{keV} \mu \mathrm{m}-1$ with a range of $4.1 \mu \mathrm{m}$ to $7 \mathrm{Li}$. The range of these particles resulted in a limited energy deposition confined to a single cell with a cell diameter ranging from 4.5 to $10 \mu \mathrm{m}$. Based on the theory, it shows that the reaction between $10 \mathrm{~B}$ and neutron allows for selective use of cancer cells by using a sufficient number of ${ }^{10} \mathrm{~B}$ so as to minimize the symptoms of normal cells at the same time [8].

BNCT itself has the advantage of turning off cancer cells, minimizing damage to healthy cells, resulting in very high ionisation power so that the radiations are barely different. The boron-10 used is localized only in cancer cells and is very low in toxication [7].

Test in vivo is a biological test using test animals by conducting cancer breeding in a medium. The use of test animals due to network approaches and the constituent cells of animal bodies has similarities with humans [8]. 
It has been conducting research on irradiating rat liver there are tumors with thermal neutron files of JRR-4 reactor[2]. The results took 17 minutes after 1 hour of irradiation trials with BSH compounds as much as $35 \mu \mathrm{g}$ boron/g to reduce the tumor. Boron's compounds are selectively killing only on tumor tissues in the rat modelling object and the BNCT is also highly recommended for benign tumor-type therapy around neural tissues [3][4]. Concentrsi Boron-10 for other than tumor tissue, i.e. blood and skin lower than tumor tissues.

It was performed a successful treatment of tumor cell reduction in rats with histology and biochemical analysis techniques [4]. Rats with tumor cells (cell lymphosarcoma) were injected with a CPA of $330 \mathrm{mg} / \mathrm{kg}$ of rat body weight, then irradiated with the neutron file for 45 minutes. After 6 to 20 hours of BNCT, the tumor has been reduced. The research was conducted on the National Nuclear centre of Kazakhstan with neutron flux specifications of 1x109 NVT/s, neutron fluence $6 \times 10^{11}$ and Gamma irradiation of $33 \mathrm{~Gy}$.

Test in vivo conducted after obtaining the design of the most optimal beam port of the translucent system, resulting in the design of the collimator system as in Figure 1 the research continued with the BNCT in the $3 \mathrm{~cm}$ aperture width.

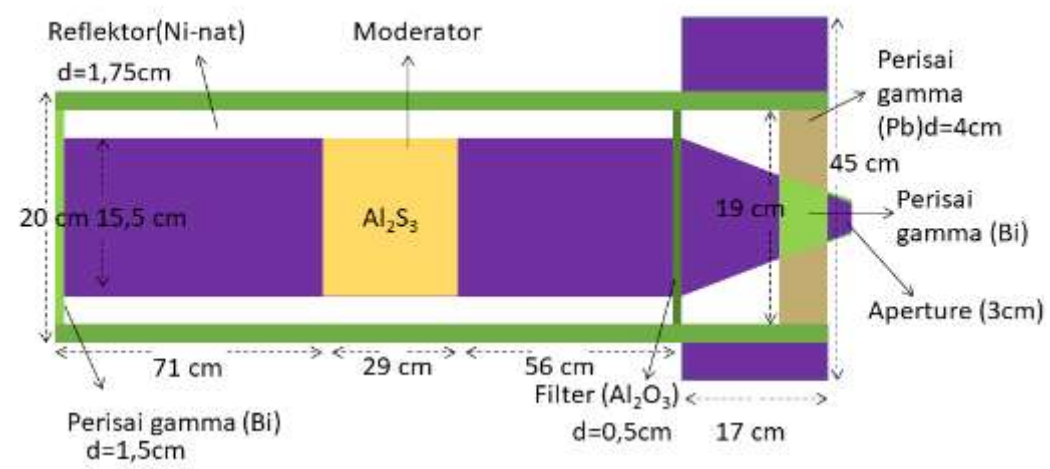

Fig 1. Design System Colimator [9]

\section{Research Metode}

In this research using Monte Carlo N-Particle eXtended (MCNPX) version 2.6.0 software. That is installed on the Personal Computer device with specification Processor Intel® Core (TM) i3-3217U CPU @ 1.80 GHz, RAM 4 GB, Operating System Windows 8.1 64-bit. Some software are supporting in Microsoft Office research process, Notepad + +, command Prompt (CMD), Vised (Visual Editor) version X_22S-5.

This research is a continuation of the research on the optimization of the design of the collimator [9]. So the research flow showed in Figure 2. 


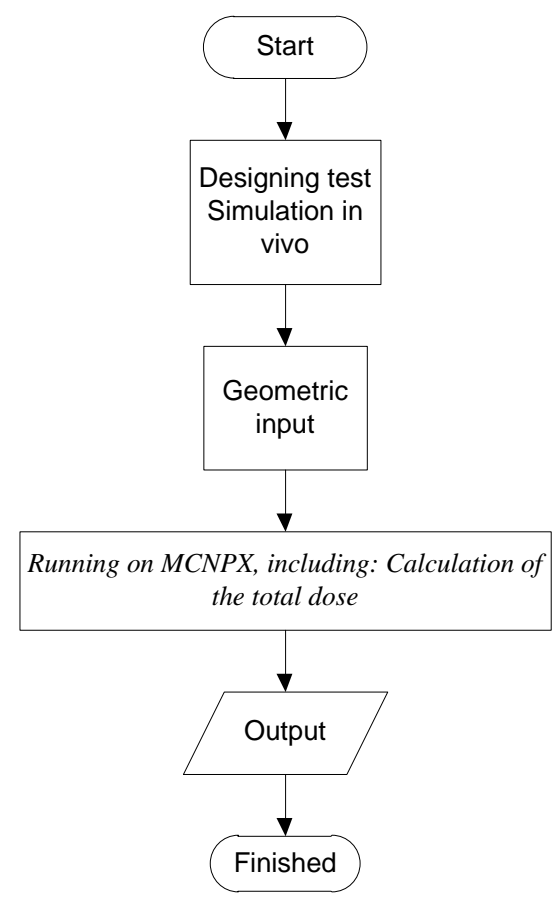

Fig 2. Research plot

The In vivo test design is a simulated geometry of test samples. The simulation of this test sample geometry shows that the laboratory rat object has already injected the cancerous cell used. Model mice that became a reference to the design of test in vivo with MCNP has been determined [5].

Modeling of rats carried out with an elipsoid wake-up approach. A Sample of the tumour used is a part of the liver of rats modelled muzzle as well. The geometry of the modeling of rat body with Elipsoida is the most simple model of mice compared to the NCTplan model or Xplan model as in the research conducted [1]. For the modeling of mice that will be tested in vivo [9] as in Figure 3.

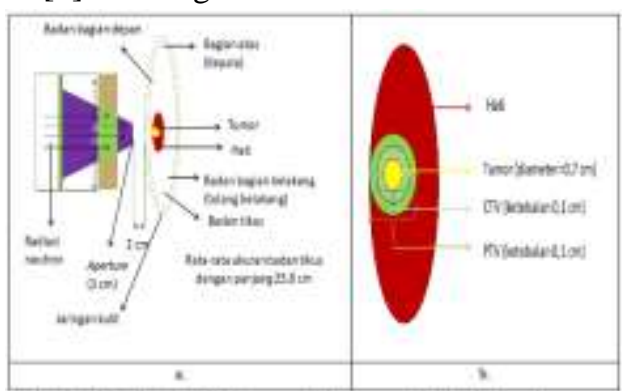

Fig. 3. a. Neutron radiation design test in vivo liver tumors in rats b. Tumor area on rat liver 


\section{$3 \quad$ Result and Discuccion}

\subsection{The results of the research}

\subsubsection{Neutron flux}

The simulation of this test in vivo is done using the optimized system specification by continuing to the test in vivo section using MCNPX software with neutron source according to the output of the collimator with MCNPX input code as in Appendix 2. Neutron flux obtained after irradiation with the concentration of Boron-10 optimum $47 \mu \mathrm{g} / \mathrm{g}$ tumor data output for skin tissues and healthy liver tissue is subdivided into Table 1.

Table 1. Neutron flux data Output for BNCT in vivo test radiation

\begin{tabular}{|c|c|c|c|c|c|c|}
\hline Tissues & $\begin{array}{l}\text { Фtermal } \\
\left(\mathrm{n} / \mathrm{cm}^{2}\right. \\
\text { s) } \times 10^{4}\end{array}$ & $\begin{array}{c}\text { Фepitermal } \\
\left(\mathrm{n} / \mathrm{cm}^{2} \mathrm{~s}\right) \mathrm{x} \\
10^{5}\end{array}$ & $\begin{array}{c}\text { कneutron } \\
\text { cepat } \\
\left(\mathrm{n} / \mathrm{cm}^{2} \mathrm{~s}\right) \\
\mathrm{x} 10^{6}\end{array}$ & $\begin{array}{c}\Phi_{\text {total }} \\
\left(\mathrm{n} / \mathrm{cm}^{2}\right. \\
\mathrm{s}) \mathrm{x} \\
10^{6}\end{array}$ & $\begin{array}{c}\text { Neutron } \\
\text { dosing } \\
\text { Rate } \\
(\mathrm{Gy} / \mathrm{s}) \\
\text { x } 10^{-5}\end{array}$ & $\begin{array}{c}\text { Gamma } \\
\text { dosing } \\
\text { Rate } \\
(\mathrm{Gy} / \mathrm{s}) \\
\times 10^{-6} \\
\end{array}$ \\
\hline Skin & 5,6 & 1,2 & 1,5 & 1,7 & 3,9 & 5,3 \\
\hline $\begin{array}{l}\text { Healthy } \\
\text { Liver }\end{array}$ & 3,5 & 7,7 & 2,3 & 3,1 & 7,3 & 7,3 \\
\hline
\end{tabular}

\subsubsection{BNCT test dose in vivo value on the tissue}

Table 2 Dose value for in vivo radiation test BNCT on the network

\begin{tabular}{|c|c|c|c|c|c|c|}
\hline Tissue & Depth $(\mathrm{cm})$ & $\begin{array}{c}\text { Neutron } \\
\text { scattering } \\
(\mathrm{Gy} / \mathrm{s}) \times \\
10^{-5}\end{array}$ & $\begin{array}{l}\text { Foton } \\
(\gamma) \\
(\mathrm{Gy} / \mathrm{s}) \\
\times 10^{-9}\end{array}$ & $\begin{array}{l}\text { Boron } \\
(\mathrm{Gy} / \mathrm{s}) \\
\times 10^{-9}\end{array}$ & $\begin{array}{l}\text { Proton } \\
(\mathrm{Gy} / \mathrm{s}) \\
\times 10^{-8}\end{array}$ & $\begin{array}{l}\text { Total } \\
\text { Gy/s) } \\
\times 10^{-} \\
4\end{array}$ \\
\hline Skin & $0,0-0,02$ & 3,93 & 0,194 & 0,271 & 2,13 & 1,26 \\
\hline $\begin{array}{l}\text { Healthy } \\
\text { Liver }\end{array}$ & $\sim 2,02$ & 7,3 & 8,84 & 2,80 & 1,36 & 2,33 \\
\hline Tumor & $\sim 2,04$ & 3,26 & 0,832 & 2,27 & 2,2 & 900 \\
\hline
\end{tabular}

\subsection{Discussion}

The radiation dose is the amount of radiation energy absorbed by its material. The calculation of normal radiation dose is called dosymmetry. In this research, there are several tissues that are traversed by radiation process including skin tissue, healthy tissue (healthy liver tissue) and tumor tissue. The three tissues have different radiation dose values, and are 
influenced by some components including the dose of scattering, photon dose (gamma), boron dose, and proton dose. These values are obtained by performing calculations from neutron flux data in table 1 namely dosage calculations for skin tissues and healthy tissues. So that it can be displayed dose scattering, photons, boron, proton and the total dose on Table 2.

Table 2 looks that the value of some of the dose calculation results for the skin is smaller than on healthy liver tissues. The total dose of the liver tumor tissues $900 \times 10^{-4} \mathrm{~Gy} / \mathrm{s}$ with the Boron- 10 concentration used amounted to $47 \mu \mathrm{g} / \mathrm{g}$ tumors. From the total dose value on the tumor tissues can be deduced the total dose value for skin tissues and healthy liver tissue is still within the safe boundary, so that the radiation process for the test in vivo is still higher for tumor tissues.

BNCT Dosimmetry in vivo tests on tumor tissues with a maximum dose 50 Gy produces an irradiation time for the liver tumor simulation tissue on the rat liver is $\sim 9$ minutes. The old results of radiation in the tumor tissues are carried out so that tumor tissues can be reduced but the surrounding healthy tissues are still in a safe dose of radiation.

\section{Conclusions}

Neutron flux obtained after irradiation with the concentration of boron 10 optimum as much as $47 \mathrm{~g}$ tumor data output for skin tissues (5.6 thermal flux, 12 flux epitermal and 150 rapid neutron flux) $(\mathrm{n} / \mathrm{cm} 2 \mathrm{~s}) \times 10^{4}$ and healthy liver tissue 3.5 thermal flux, 77 flux Epitermal and 230 rapid neutron flux) (n/cm2 s) x $10^{4}$. Neutron dose rate $3.9 \times 10^{-5} \mathrm{~Gy} / \mathrm{s}$ and for gamma dose rate $5.3 \times 10^{-6} \mathrm{~Gy} / \mathrm{S}$.

\section{Acknowledments}

The authors wish to acknowledge BATAN Yogyakarta for the use of software in ths stidy because this research is a development that was done by author for long time ago. And also do not forget the authors also say many thanks to the Sari Mulia Universty for providing an opportunity to publish this article.

\section{References}

[1] Liu, Y.H., Lee, P.Y., Lin, Y.C., Chou, F.I., Chen, W.L., Huang, Y.S. dan Jiang, S.H., Dose estimation of animal experiments at the THOR BNCT beam by NCTPlan and Xplan, Applied Radiation and Isotopes, vol.88, pp. 125-128 (2014)

[2] Fujii, H., Matsuyama, A., Komoda, H., Sasai, M., Asano, T., Doki, Y., Kirihata, M., Ono, K., Tabata, Y., Kaneda, Y., Sawa, Y. dan lee, C.M. : Cationized gelatin-HVJ envelope with sodium borocaptate improved the BNCT efficacy for liver tumor in vivo. Radiation Oncology. 6:8 (2011)

[3] Fujimoto, T., Andoh, T., Sudo, T., Fujita, I., Moritake, H., Sugimoto, T., Sakuma, T., Akisue, T., Kawabata, S., Kirihata, M., Suzuki, M., Sakurai, Y., Ono, K., Fukumori, Y., 
Kurosaka, M. dan Ichikawa, H. : Boron neutron capture therapy (BNCT) selectively destroys human clear cell sarcoma in mouse model. Applied Radiation and Isotopes. Vol. 73, pp. 96-100 (2013)

[4] Fujimoto, T., Andoh, T., Sudo, T., Fujita, I., Fukase, N., Takeuchi, T., Sonobe, H., Inoue, M., Hirose, T., Sakuma, T., Moritake, H., Sugimoto, T., Kawamoto, T., Fukumori, Y., Yamamoto, S., Atagi, S., Sakurai, Y., Kurosaka, M., Ono, K., Ichikawa, H. dan Suzuki, M.: Potential of boron neutron capture therapy (BNCT) for malignant peripheral nerve sheath tumors (MPNST). Applied Radiation and Isotopes, Vol. 106, pp. 220-225 (2015)

[5] Konijnenberg, M.W., Bijster, M., Krenning, E.P. dan de Jong, M. : A Stylized Computational Model of the Rat for Organ Dosimetry in Support of Preclinical Evaluations of Peptide Receptor radionuclide Therapy with ${ }^{90} \mathrm{Y},{ }^{111} \mathrm{In}$, or ${ }^{177} \mathrm{Lu}$, The Journal of Nuclear Medicine, vol. 45, pp. 1260-1269. (2004)

[6] Masutani, M., Baiseitov, D., Itoh, T., Hirai, T., Berikkhanova, K., Murukami, Y., Zumadilov, Z., Imahori, Y., Hoshi, M. dan Itami, J. : Histological and biochemical analysis of DNA damage after BNCT in rat model (2014)

[7] Sardjono, Y. :Pengenalan teknologi dan Aplikasi Boron neutron Capture Therapy(BNCT). Caraka Nuklida, No. ISSN 0853-4942, vol. 28, pp.26 (2013)

[8] Sauerwein, W., Wittig, A., Moss, R. dan Nakagawa, Y. : Neutron Capture Therapy. Springer. New York. ISBN 978-3-642-31333-2 (2012)

[9] Wusko, IU., Kusminarto, Sardjono., Y. : The Optmization of Collimator Material and in vivo Testing Dosimetry of Boron Neutron Capture Therapy (BNCT) onRdial Piercing eam Port Kartini Nuclear Reactor by Mote Carlo N-Particle Extended (MCNPX) Simulation Method. Vol.3, Num. 1, pp.29-35. Indonesian Journal of Physics and Nuclear Applications. FSM UKSW Publication (2018) 